\title{
A passagem intérmina de Maria Velho da Costa
}

\author{
"Não foi nunca o lugar que tu buscaste, mas a passagem intérmina, \\ minha vida que não descrevo - chamo."
}

Maria Velho da Costa, Da Rosa Fixa

Por uma questão geracional e por errâncias várias, nunca poderei invocar a condição de leitora da primeira hora de Maria Velho da Costa; os meus primeiros encontros com a sua escrita foram tardios e travessos: começaram pela leitura dirigida das Novas Cartas Portuguesas, em meados dos anos 80, passaram pela curiosidade com que me aproximei das suas crónicas em Desescrita e em O Mapa-cor-de-rosa, algures na década de 90, e contaram com o entusiamo diante da peça Madame, levada a palco, no TNSJ, em 2000. Sou aqui prova de quanto podem ser longos e insondáveis os caminhos que nos conduzem às obras maiores, pois houve muitos outros desvios antes do embate frontal, em 2008, com Myra, esse ser mutante que dá nome ao "road romance" mais inesquecível da ficção contemporânea.

As grandes obras literárias, ou artísticas em geral, (co)movem-nos tanto mais quanto as suas qualidades estéticas forem ao encontro daquelas que, num determinado momento, são as nossas próprias questões, expectativas e desejos, e a verdade é que, pelos primeiros anos deste século, eu andava justamente à procura daquilo que resgatasse a condição migrante e a experiência exílica do fugaz sensacionalismo a que nos habituaram os media, e do que as aprofundasse para além do registo documental da "história de vida", das estatísticas, das intervenções e dos discursos programáticos.

Myra levou-me a não adiar mais o encontro com o universo da escritora, que se não é particularmente extenso, apresenta-se muito compacto, exigente e implacável, como é em geral timbre dos autores maiores. Li então todos os seus romances e deixei-me envolver, de modo especial, por Casas Pardas e Irene ou o Contrato Social. Mas nem essa imersão à rebours iria beliscar, o mínimo que fosse, a minha primeira admiração por Myra, pelo que continuaria a não subscrever algumas reservas de passagem que aquele que viria ser o seu último livro parece ter suscitado a alguns dos mais antigos e fiéis leitores de Maria Velho da Costa, ao verem nele uma alegada quebra de fulgor estético, proporcional à sua maior "legibilidade"... Não me caberá rebater esses pressupostos aqui; apenas apontarei que reconheço nessa histó- 
ria em torno de uma jovem imigrante de Leste e um cão rimbaldiano, nada mais, nada menos que a história prometida pela autora em período pós-revolução, aquando de acesas discussões em torno dos "parasitas da consciência alarmada e desperta" (Costa 1994: 66), alegadamente dividida entre, por um lado, o mundo e, por outro, as palavras. Ora, "Entre Actos, Cravo", a autora tinha registado, exactamente no último dia do ano de 1975, o seguinte projecto: "Que um dia hei-de dar uma história como uma magnólia, aberta, grande, branca, toda bem ligada, uma harmonia. [E acrescentava, por precaução e alguma ironia, depreende-se] Mas não é nenhuma promessa segura" (idem: 12). Se dúvidas houvesse sobre a distorção provocada por uma perspetiva demasiado bipolarizada da modernidade estética, prolongada entretanto na oposição entre "literatura transitiva" e "literatura intransitiva", aquele romance centrado exclusivamente em "seres em trânsito", literal e metaforicamente, é prova evidente de como o "realismo visionário" de Maria Velho da Costa resolve completamente essa dicotomia, tantas vezes transformada numa espécie de aporia literária e estética. Cabe ainda acrescentar que toda a escrita de Maria Velho da Costa, em Myra como noutras narrativas e crónicas, ultrapassa também a oposição entre poesia e prosa, pois que o seu labor sempre radicou nessa "misteriosa sufocação cantante" que a transcendia, como em 0 Livro do Meio o admitiu, embora não o confundisse com nenhum mister sagrado (Carvalho/ Costa 2006: 407).

Talvez aquilo que mais preze no acto de ensinar literatura, ou melhor, de ensinar com literatura, seja o privilégio de eu própria ir entendendo "do que nos comove e move para onde" (Costa 1994: 11), e fazer com que os estudantes possam também experimentar esse processo de (auto-)transformação na forma de ver/ler o mundo, pelo que um dos momentos de que mais me orgulho na minha condição de professora, seja aquele em que entusiasmei uma estudante para a leitura tanto de Myra como da restante obra de MVC, o que a levaria a decidir-se pelo seu estudo global como projeto de doutoramento. Na minha função de sua orientadora, fui natural e simultaneamente participante e devedora de um percurso hermenêutico que culminaria numa "poética de au(c)toria", defendida como tese na Faculdade de Letras do Porto, e posteriormente publicada pela INCM (Dias 2018).

Ao escrever este depoimento, que me foi solicitado pelos editores deste número dos Cadernos de Literatura Comparada dedicado a Maria Velho da Costa - entretanto apanhado de surpresa e tristeza pela sua morte -, sou levada a pensar que há doze anos que eu vinha interiormente a despedir-me da autora, lamentando a ausência do seu ofício de "cismadora e vidente do visível" (Costa 2001: 160), da sua extraordinária ventriloquia, da sua enorme sensibilidade a todas as formas de desvario e àquilo a que ela própria chamou "crioulo galáctico". Há doze anos que tudo levava a crer que a própria Maria Velho da Costa se tinha despedido, definitivamente, da literatura, deixando assim de esquadrinhar as dobras do presente e do passado com a sua enorme mestria da língua portuguesa "mais cheia de subtis hierarquias de castas que o sistema de ângulos de vénias dos japoneses" (idem: 125). Era, portanto, também há doze anos que eu sentia falta do seu renovado sobressalto de "Espécie de Barragem contra a Voz Passiva" (Costa 1996: 135), da sua argúcia dura, (auto-)irónica e culta de morder a realidade até ao osso da prosa. 
E agora, que nem Maria de Fátima de Bivar [Moreira de Brito] Velho da Costa, nem Maria Agustina Ferreira Teixeira Bessa respiram estes nossos dias comuns, tomo consciência de que há uma parte de mim, leitora, que também se extinguiu, na definitiva impossibilidade de alguma vez ler um Livro do Meio da Casa urdido pelas duas escritoras que, embora à distância, mais se mereceram e mais cedo elevaram a fasquia do romance em Portugal no século XX e inícios deste século. Muito eu teria gostado de ler essa (im)possível obra a meias, numa outra versão de tropismos e ligações perigosas entre mulheres... Chego a imaginá-la como um baú de ressonâncias ecoando entre quartos, cozinha e salas, atravessando espelhos e paredes de mármore como faúlhas de vozes firmes a pairar sobre o interior e o exterior da(s) casa(s). Gostava, em suma, de ver nela uma metalepse de prolongamento d' "A ponte sobre Serralves" (Costa 2001a), onde as duas romancistas se encontrassem nessa casa "[que] não dorme nunca" (idem: 123) e se juntassem a D. Laura, a Deodata e ao Jardineiro Prodigioso, personagens do referido conto que, por sinal, Maria Velho da Costa dedicou precisamente a Agustina e Sophia... E depois disso - quero crer - mais ninguém sentiria necessidade de perguntar onde termina a vida e começa a arte. E vice-versa.

[31 de Maio de 2020]

\section{Bibliografia}

Carvalho, Armando da Silva/ Costa, Maria Velho (2002), O Livro do Meio, Lisboa, Caminho.

Costa, Maria Velho da (1994), Cravo, $2^{\mathrm{a}}$ edição, Lisboa, Publicações Dom Quixote [1 ${ }^{\mathrm{a}}$ ed., 1976]

- - (1996), Casas Pardas, $4^{\mathrm{a}}$ edição, Lisboa, Publicações Dom Quixote [1 ${ }^{\mathrm{a}}$ ed., 1986]

-- (1999), Da Rosa Fixa, $2^{\mathrm{a}}$ edição revista, Lisboa, Quetzal Editores.

- - (2001), Irene ou o Contrato Social, $2^{\mathrm{a}}$ edição, Lisboa, Publicações Dom Quixote [1 ${ }^{\mathrm{a}}$ ed., 2000]

- - (2001a), "A ponte de Serralves" in Porto. Ficção, Porto, Edições Asa: 109-123.

-- (2008), Myra, Lisboa, Assírio \& Alvim. 